\title{
Research on Professional Curriculum Group Construction for Machinery Manufacturing Automation Cultivated Based on Application Ability
}

\author{
Hansong Yang \\ School of Engineering \\ Huanghe Science and Technology College \\ Zhengzhou, China
}

\author{
Defeng Gao \\ School of Engineering \\ Huanghe Science and Technology College \\ Zhengzhou, China
}

\author{
Xiaodong Wang \\ Henan Boda Microwave Equipment Co., Ltd. \\ Zhengzhou, China
}

\begin{abstract}
The teaching reform conducted around curriculum group in domestic colleges is still at the beginning stage. Colleges mainly create their characteristic specialty and determine profession direction and talents according to enterprises' requirements for talents in terms of their knowledge, ability and quality. In recent years, with the national education and teaching being deepened constantly, colleges also conduct reforms continuously in terms of talent cultivation. Facing the urgent demand for application-oriented innovative talents by the society, colleges shall make certain changes in talent cultivation specification in order to adapt to the needs of society. At the same time, to meet the "public innovation and entrepreneurship" as well as transformation development, construction of certain curriculum system and professional curriculum group has become one of the main ways for talent cultivation. This paper takes mechanical specialty as an example, and constructs the professional curriculum group suitable for cultivation of application-oriented innovative talents.
\end{abstract}

Keywords-application ability cultivation; professional curriculum group; construction mode

\section{INTRODUCTION}

Machinery specialty is classified as mechanical engineering in accordance with Grade 1 Discipline, and is classified as machine manufacturing and automation according to Grade 2 Discipline. Classify according to disciplines, take social and economic development needs into consideration according to characteristics of the discipline, to reflect the development trend of science and technology, carry out curriculum system optimization and teaching from the perspective of overall optimization, re-examine and break the barriers between discipline curriculums, and find out the internal logic between the courses as well as the connection and integration in terms of structure. The knowledge of specialty and professional direction is formed by curriculum group system, the ability and quality of modularized structural curriculum group system is constructed by traditional specialty, the setting of curriculum has carried forward the former Soviet Union pattern. And there are many discipline branches which establish a system of their own, pursuing the completeness of single lesson, therefore, many defects appear, such as repeated course contents, too many class hours and aging knowledge structure.

\section{CURRICULUMS SYSTEM CONSTRUCTION BASED ON ABILITY CULTIVATION}

Establish the multi-level, whole process and comprehensive practical teaching system directed by the "idea of large-scale engineering". Reform the traditional practical teaching and engineering education, widen resources, extend the time and space, expand connotation, and construct practical teaching system of "one main line, three levels and five platforms" around school's target positioning of "facing production line, cultivating application-oriented engineering technical talents with high quality" with "idea of large-scale engineering" as guidance. One main line: take engineering practice and innovative ability cultivation as the main line. Three levels: divide ability cultivation into three levels such as engineering foundation ability, professional skills and engineering practice ability as well as science and technology innovation ability. Five training platforms refer to five practice and training platforms for engineering foundation ability training, professional foundation training, professional integrated training, enterprise engineering practice training and science and technology innovation training. All these have created a comprehensive cultivation environment with whole process for cultivating and improving students' engineering practice and innovation ability. Broaden resources and fully develop and use various practical teaching resources of the school and society, which include mechanical engineering experimental teaching demonstration center and scientific research base for mechanical engineering disciplines on 
campus, as well as the talent cultivation base off campus, scientific research cooperation enterprise, colleges in joint school-running both at home and abroad and so on. Extending time and space refers to extend the time and space of practical teaching scientifically, including open experiment, second classroom, science and technology innovation, academic competitions, scientific research and other extracurricular activities; expanding connotation refers to integrate the professional knowledge of machine, electricity, computer, information, management, etc. organically, pay attention to the cultivation of students' engineering practice and innovation ability, and to establish rigorous scientific attitude and team spirit.

\section{CONSTRUCT THE PROFESSIONAL CURRICULUM GROUP WITH MAIN COURSE AS THE CORE ACCORDING TO OVERALL FUNCTION OF THE CURRICULUM GROUP}

\section{A. Common Basis and Quality Expansion Curriculum Group}

Cultivate students to have both the humanities, social sciences and scientific literacy, expand their horizons, as well as develop their ideology and morality, legal awareness and sense of social responsibility. This curriculum group includes all the "Two Classes" education in terms of ideology and politics, humanities and social sciences; the courses that are necessary for engineering students such as the mathematics, college physics, college English, college computer foundation, C language programming, college chemistry, and sports. Develop good humanities and accomplishment through the learning of the public elective courses of literature, art and social science. The curriculum group involves music, literature, art appreciation, pop culture, college student psychology, industrial business management, engineer professional ethics and responsibility, professional English, production plan and control, product design and manufacturing quality management and other courses.

\section{B. Curriculum Group of Professional Basis}

It requires students to master the basic theory of mechanics and analysis methods, master the expression of design concept graphics, engineering materials application, mechanical product design, precision design and geometric quantity detection technology and other basic theory and methods. The curriculum group includes Theoretical Mechanics, Principle of Mechanics, Mechanical Dynamics Foundation and other courses. And it also includes engineering drawing, mechanical engineering materials, Heat Transfer Theory, mechanical principle, mechanical design, Basic Technology of Exchangeability and Measurement, computer-aided design, CAD engineering drawing practice, curriculum design of part and assembly measuring, curriculum design of mechanical product design and other courses.

\section{Mechatronics Curriculum Group}

It requires students to master the basic theory, analysis and design methods of control system; detection method of the system's physical quantities in common use, analysis and processing of signal; master the working principle of test equipment in common use and its application; be familiar with the characteristics and application of hydraulic-pneumatic control system. The curriculum group includes electrical and electronic technology, engineering control technology, engineering testing technology, mechanical and electrical control technology, hydraulic and pneumatic transmission, electrical and electronic practice, curriculum design of mechanical and electrical hydraulic control technology and so on.

\section{Mechanical Manufacture and Process Technology Curriculum Group}

It requires students to master the basic theory of mechanical manufacture technology, mechanical manufacturing equipment, automatic manufacturing system and advanced manufacturing mode. The curriculum group includes materials processing technology, mechanical manufacturing and digital processing technology, mechanical equipment design, modern manufacturing technology, metalworking practice, product innovation design and manufacturing comprehensive practice.

\section{E. Professional Knowledge Expansion Curriculum Group}

Further expand the latest cutting-edge technology of machinery and equipment manufacturing industry, interdisciplinary crossing technology as well as the advanced fields of this specialty involved in on-duty practice enterprise. The curriculum group includes reverse technology and rapid prototyping, mechanical optimization design, automatic manufacturing technology, manufacturing technology history and frontier lectures, network design and manufacturing, modern manufacturing information system and equipment management and maintenance as well as other professional elective courses.

\section{Practical TEACHING CURRICUlum Group S ystem}

Practical teaching cultivation mode cultivates students' operation ability and the ability to solve engineering practical problems. Practical teaching and theory teaching are conducted simultaneously, highlighting the engineering application and practice innovation of the teaching contents. Various practical teaching links are conducted step by step according to basic skill level, comprehensive application ability and preliminary design capability level, engineering practice and innovation ability level. Phased learning shall be implemented for enterprises. The entire practical teaching system include public foundation practice, foundation practice of mechanical design, foundation practice of mechatronics, technical practice of machinery manufacturing, comprehensive ability practice and other practical teaching curriculum group.

The practical teaching curriculum system of this specialty is designed for machinery manufacturing, to strengthen the cultivation of professional knowledge application ability and comprehensive quality. In the background of innovative talents cultivating, enterprise cultivation is divided into enterprise rotational learning, fixed post practice, project design, graduate design and other links, involving in enterprise product development, production, management, etc., integrate teaching theory and enterprise practice, and put into use. Enterprise 
learning adopts the method integrating "rotational learning", "fixed post learning" and "project participation", focusing on "doing by learning", "learning by doing" and "thinking by doing." Adopt the "double-tutor system" teaching, conduct multiple posts rotational training against enterprise production under the common guidance of "school tutor" and "enterprise tutor", or participate in enterprise projects, familiar with the whole process of product R\&D - technology - production assembly - inspection (test). Through enterprise learning, cultivate students' good professional ethics of engineers, engineering awareness and social responsibility, to further strengthen their ability to analyze production line site and to solve practical engineering problems.

After the teaching content of this base is reformed by science and technology innovation, it is formed by open experiment, science and technology production, competition and social practice and other modules. Integrate the machine foundation innovative practice content of basic practical teaching platform as well as the mechanical professional innovative practice content of mechanical professional practical teaching platform into the modules of open experiment and technological production as well as competition. Social practice module includes military training, two classes practice and second classroom practice and so on. According to students' personality and needs, set the teaching project focus of science and technology innovation base flexibly, and strengthen the comprehensive, design and innovative practical teaching.

Set the practical teaching project collectively on the mechanical foundation practical teaching platform, mechanical professional practical teaching platform and science and technology innovation base by virtue of optimizing the adjustment and reforming the practical teaching contents. Among which, mechanical foundation practical teaching platform has planned the practical teaching projects, and mechanical professional practical teaching platform and science and technology innovation base have also planned the practical teaching projects respectively. The new mechanical professional practical teaching system constructed based on the abovementioned shall be implemented according to the adjusted and reformed practical teaching content. In recent years, meticulous design has been conducted regularly for the cultivation program of mechanical specialty. Professional cultivation program includes theoretical teaching cultivation plan and practical teaching cultivation plan, of which, practical teaching cultivation plan includes structural table of cultivation program, process table of cultivation program, schedule of practical teaching link and the progress table of cultivation program divided by semesters, which has strengthened the important role of practical teaching in the whole professional teaching. In addition, the implementation of practical teaching cultivation program is mainly completed through practical teaching outline and practical teaching classroom reform. The new compiled practical teaching outline has highlighted the organic combination of basic practice with comprehensive, design innovative practice, which has added the proportion of comprehensive, design and innovative practice; practical teaching classroom reform pays attention to the reform of practical teaching methods and means, focusing on the supervision on such links as teaching plan, classroom teaching, teaching journal and guidance as well as classroom evaluation of the practical teaching link.

\section{CONCLUSION}

Cultivate talents based on innovation, and in the teaching process, it is very crucial to construct curriculum system and curriculum group, which plays special meaning in the process of talent cultivation, curriculum organization, and teaching supervision as well as evaluation. It can organize the teaching better, playing a more important role in the aspect of machine and equipment utilization as well as the organization of practice advisor in the process of unifying practical teaching.

\section{ACKNOWLEDGEMENT}

This paper is the funded project of national college students off-campus practice base, experimental specialty of talent cultivation mode reform of undergraduate engineering education in regular institutions of higher education of Henan province, the project of "professional comprehensive reform pilot" of colleges, characteristic specialty of Henan province as well as the research topic of talent cultivation mode reform of Huanghe S\&T College.

\section{REFERENCES}

[1] Zhang Zhe, The Discussion of the Curriculum Reform of mechanical manufacturing technology, Journal of Zhangjiakou Vocational and Technical College.Vol.22,pp.70-71,2009.

[2] Yu Ying-hua,Zhang Xing-yuan. Reform and Practice in the Basic Course Design of Mechanism Manufacture Technology. Experiment Science \& Technology. Vol.7,pp.94-97,2009.

[3] Xu Feng, Zuo Dunwen. Study on teaching reform of mechanical manufacturing technology course. Journal of Higher Education Management. Vol .1 ,pp.90-93,2007.

[4] Yang Xiao-fan, Zheng Tian yi. Reform and Practice of Mechanism Manufacture Technology Basis. Journal of $\mathrm{Ji}$ mei University. Vol .1,pp94-96,2005.

[5] Han Bian-zhi, Wang Dong, Zhang Yin-xi. Trial and Reform in the Manufacturing Technology Foundation Course Based on the Ability Training. Journal of Taiyuan University of technology. Vol. 29,pp.8688,2011 . 